\title{
РЕЦЕНЗІЇ
}

\author{
кОЛОДІЙ А. М., \\ доктор юридичних наук, професор, \\ заслужений юрист України, \\ академік Академії наук \\ вищої школи України, \\ директор \\ (Юридичний інститут \\ ДВНЗ «Київський національний \\ економічний університет \\ імені Вадима Гетьмана»)
}

DOI https://doi.org/10.32842/2078-3736/2020.6.1.35

\section{РЕЦЕНЗІЯ НА МОНОГРАФІЧНЕ ДОСЛІДЖЕННЯ І.Д. ПАСТУХА «ЗАПОБІГАННЯ ТА ВРЕГУЛЮВАННЯ КОНФЛІКТІВ ІНТЕРЕСІВ У ДІЯЛЬНОСТІ ПУБЛІЧНОЇ АДМІНІСТРАЦІї: АДМІНІСТРАТИВНО-ПРАВОВЕ ДОСЛІДЖЕННЯ ${ }^{1}$}

У Видавничому центрі «Кафедра» у 2020 р. вийшла друком монографія І.Д. Пастуха «Запобігання та врегулювання конфліктів інтересів у діяльності публічної адміністрації: адміністративно-правове дослідження», яка є комплексним дослідженням запобігання та врегулювання конфліктів інтересів у діяльності публічної адміністрації.

Суспільна довіра до публічної адміністрації є необхідним елементом функціонування демократичної правової держави. В Україні зберігається високий рівень корупції, що негативно сприймається суспільством і потребує рішучих дій. Як свідчать проведені дослідження, громадськість сприймає владу як корумпований інститут, довіра до якої має тенденцію до зменшення.

Дане монографічне дослідження буде цікавим для вищих навчальних закладів тим, що в роботі розкрито комплекс питань, які стосуються: правової природи конфлікту інтересів у публічно-правових відносинах; теоретико-методологічних засад дослідження конфлікту інтересів; змісту публічних правовідносин як сфери виникнення конфлікту інтересів; поняття та видів конфлікту інтересів; поняття та складових елементів адміністративно-правового механізму запобігання та врегулювання конфлікту інтересів на публічній службі; системи суб'єктів запобігання та врегулювання конфлікту інтересів; порядку повідомлення та врегулювання конфлікту інтересів у публічних правовідносинах; особливостей запобігання та врегулювання конфліктів інтересів у діяльності центральних органів виконавчої влади, що спрямовуються та координуються Кабінетом Міністрів України через Міністра внутрішніх справ України; запобігання та врегулювання конфлікту інтересів у зв’язку 3 наявністю в особи підприємств чи корпоративних прав; конфліктів інтересів, що виникають у зв'язку з недотриманням обмежень щодо одержання подарунків; конфліктів інтересів, що виникають під час сумісництва та суміщення з іншими видами діяльності; конфліктів інтересів, що виникають під час спільної роботи близьких осіб; дисциплінарної відповідальності за порушення вимог законодавства щодо конфлікту інтересів; поняття та підстав адміністративної відповідальності за порушення вимог щодо запобігання та врегулювання конфлікту інтересів; сутності провадження у справах про адміністративні правопорушення,

\footnotetext{
Пастух І.Д. Запобігання та врегулювання конфліктів інтересів в діяльності публічної адміністрації: адміністративно-правове дослідження : монографія. Київ : Видавничий центр «Кафедра», 2020.
}

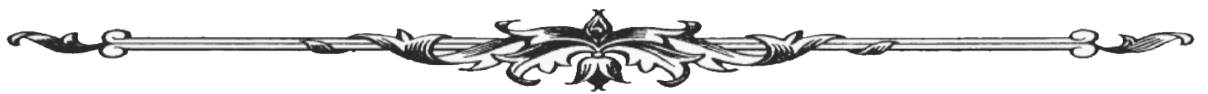


пов’язані з порушенням вимог щодо запобігання та врегулювання конфлікту інтересів; адміністративних стягнень, що накладаються за порушенням вимог щодо запобігання та врегулювання конфлікту інтересів; зарубіжного досвіду правового регулювання конфлікту інтересів та напрямків удосконалення законодавства у сфері запобігання та врегулювання конфлікту інтересів у публічно-правових відносинах.

Автор проводить аналіз чинного Закону України «Про запобігання корупції» та Закону України «Про засади запобігання та протидії корупції», який втратив чинність, у розрізі із Законами України «Про державну службу», КЗпП та КупАП, а також пропонує внесення змін та доповнень до: ст. 172-6 Кодексу України про адміністративні правопорушення та доповнити ст. $172^{7-1}$ «Порушення строків повідомлення та врегулювання конфлікту інтересів»; ст. $172^{7-2}$ «Порушення строків про повідомлення та врегулювання конфлікту інтересів»; ст.ст. 1, 3, 28 Закону України «Про запобігання корупції» та доповнити ст. 35-1 «Діяльність спеціальних (тимчасових) комісій по урегулюванню конфлікту інтересів»; ст. 66 Закону України «Про Національну поліцію» та викласти в такій редакції: «Поліцейський не може під час проходження служби займатися іншою оплачуваною діяльністю, крім науково-педагогічної, наукової або творчої, медичної практики, інструкторської та суддівської практики зі спорту».

Таким чином, праця І.Д. Пастуха є першим монографічним дослідженням, присвяченим запобіганню та врегулювання конфліктів інтересів у діяльності публічної адміністрації. У ній представлено авторський погляд на сутність та структуру конфліктів інтересів, їх види, наведено визначення відповідних детермінант, із позиції правового розуміння: розкрито генезис становлення та розвитку дослідження проблем запобігання та врегулювання конфлікту інтересів, досліджено поняття та складові елементи адміністративно-правового механізму запобігання та врегулювання конфлікту інтересів у діяльності публічної адміністрації.

Роботу адресовано фахівцям-теоретикам, які займаються дослідженнями в галузі адміністративного права й процесу, а також викладачам, аспірантам, студентам юридичних навчальних закладів.

Таким чином, рецензована монографія «Запобігання та врегулювання конфліктів інтересів в діяльності публічної адміністрації: адміністративно-правове дослідження», підготовлена к.ю.н., доцентом І.Д. Пастухом, є комплексним дослідженням, заслуговує позитивної оцінки та має надзвичайне значення не лише у світлі наукового дослідження, а й як посібник для юристів-практиків та суб’єктів публічної адміністрації і може бути рекомендована до друку.

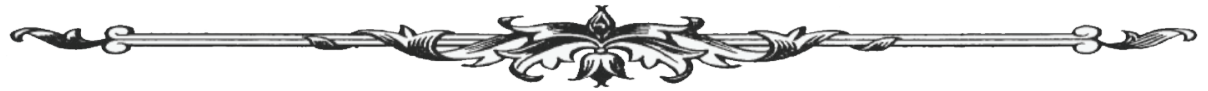

